\title{
Care facilities for Germans in Thailand and Poland: making old age care abroad legitimate
}

\author{
By DésiRÉE BENDER* E CORNELIA SCHWEPPE*
}

\begin{abstract}
This article looks at old age care facilities abroad that target people who live in Germany. Such facilities have been established in Southeast Asia (mainly Thailand) and in Eastern Europe (mainly Poland). Given that they challenge central guiding orientations for old age care in Germany, considerable criticisms are levelled at them, and their use is viewed with distinct scepticism. Nevertheless, some of these facilities succeed in sustaining considerable demand from Germany over quite a few years. In this article, we therefore ask what strategies and arguments they use to make them a legitimate option for people in Germany and to be established on the German market. Based on two case studies of an old age facility in Thailand and Poland, we will show how they skilfully position themselves as "better" options for residential care even though their strategies considerably vary and result in very different models of old age care. Drawing on neo-institutional organisation theories, we will show how these strategies are essential for the facilities' emergence as new players in the care market for older people from Germany.
\end{abstract}

Keywords: international retirement migration, legitimation, long-term old age care, migration in old age, old age care, organisation theories, Poland, residential old age care, Thailand.

* Désirée Bender \& Cornelia Schweppe, Institute of Education, Johannes Gutenberg University Mainz, Germany 
International Journal of Ageing and Later Life

\section{Introduction}

The provision of care for the rising numbers of old people with care needs in Germany, as in many other European countries, is subject to considerable criticism (Rothgang et al. 2012). Severe shortcomings in old age care, such as high costs, a lack of quality care, a precarious staff situation and a lack of at-home support, have been identified by many studies and pointed out in policy debates and by relatives and people who need care in old age (see below). In response, cross-border developments and transnational care arrangements have emerged over the last few years. More specifically, the employment of migrant care workers in private households has become a widespread phenomenon in many Southern and Central European countries. Germany is no exception (Böcker et al. 2017). With the number of migrant care workers estimated at up to 300,000 (Arend 2017), they have also become a significant pillar of the German old age care system.

In recent years, another border-crossing development can be observed. Instead of moving carers in, as with the migrant care workers, this phenomenon can be called a "moving of care out." It manifests through the establishment of old age care facilities abroad, catering to specific nationalities or linguistic communities. Toyota and colleagues pointed to this development for older Japanese and the establishment of a broad spectrum of care facilities targeting them, particularly in Malaysia (Toyota \& Thang 2017; Toyota \& Xiang 2012). In the last decade, this development can also be observed for people from Germany. Most of these facilities have been established in Southeast Asia (mainly Thailand) and Eastern Europe (mainly Poland) (Bender et al. 2018; Großmann \& Schweppe 2018; Horn et al. 2016). ${ }^{1}$

Old age care facilities abroad can be described not only as a relatively new actor in the transnational old age care market (drawing on Schwiter et al. 2014), but also as a new type of old age care facility (Bender et al. 2017) because the care of old people is displaced abroad, requiring old people to migrate across borders for the purpose of care. These challenges

${ }^{1}$ According to the Internet platform "Wohnen im Alter" ("living-in-old-age"; www.wohnen-im-alter.de), which is one of the main internet platforms in Germany for care options in old age in Germany and abroad, old age care facilities in the Philippines, Bosnia and Herzegovina, Bulgaria, Croatia, Rumania, Slovakia, Slovenia and Czech Republic are mentioned. To our knowledge, there are no studies on old care facilities in these countries. 
the principle of "ageing in place," which is one of the main professional and public guiding orientations for old age care in Germany (Engelmann et al. 2013). Many critical media reports (Hahn 2012; Posener 2014; Prantl 2012), along with opinion polls (Konpress and Emnid 2013) registering distinct scepticism towards care abroad, indicate that these facilities are by no means generally accepted or considered legitimate as yet. Nevertheless, a few facilities have succeeded in upholding considerable demand in Germany over several years. In this article, we therefore ask about the strategies and arguments used by these facilities when presenting themselves so that, despite the widespread criticism, they are taken up by people from Germany and become established in the German market.

Questions about how newer border-crossing old age care organisations establish themselves in the old age care market have been little researched so far (Schwiter et al. 2014, 2018). Some references can be found in studies dealing with placement agencies for migrant care workers (ibid.; Krawietz 2014). Despite criticism and scepticism, these have become established in great numbers due to a growing demand for migrant care workers in private households in Germany. According to a study by the German consumer organisation and foundation Stiftung Warentest (2017), more than 250 placement agencies of live-in migrant care workers are active in the country. In studying how these agencies became established in the market, a key finding shows that they skilfully pick up on relevant criticisms of old age care in Germany and present themselves as qualitatively superior to the offers of care available (Schwiter et al. 2014).

The present article is based on the research project "Moving Old Age Care Abroad - New Facets of Ageing and Care Arrangements," which examines old age care facilities in Thailand and Poland that target and serve people from Germany. ${ }^{2}$ Based on two case studies of old age care facilities in Thailand and Poland that have succeeded in maintaining themselves over a longer time period, we analyse how they project themselves to be taken up as an alternative to the care options existing in Germany.

We begin by explaining the main strands of criticism of old age care facilities in Germany as well as the criticism of using care facilities abroad.

\footnotetext{
${ }^{2}$ The facilities in Thailand also target and serve people from other German-speaking countries (mainly Switzerland).
} 
International Journal of Ageing and Later Life

Both critiques are important, as they form the background against which the old age care facilities abroad develop strategies to establish themselves in the German market. We also elaborate on the circumstances and reasons why these facilities especially have emerged in Thailand and Poland. We then proceed to the case studies of the two care facilities. Although these facilities are very different, our comparison shows some noticeable similarities. To conclude we explain the significance of the strategies the facilities use for their establishment in the care market in Germany.

\section{Methodological Approach}

The article draws on data collected in the research project "Moving Old Age Care Abroad - New Facets of Ageing and Care Arrangements." The project focuses on the analysis of the contexts in which these facilities emerge, the motivations of the (migrating) residents and/or their relatives, the living conditions in these facilities, and the strategies and arguments developed by the facilities to position themselves as a favourable option for old age care of people from Germany. The following article focuses on the last aspect. The study was conducted between 2014 and 2018 during seven field trips. The empirical data from Thailand were collected in the course of six 2- or 3-week field trips to the facilities between 2014 and 2018, and from Poland in the course of two 3-week field trips in 2016. Each field trip to Thailand and Poland was conducted by two researchers. Due to the different locations of the facilities, research sites included rural areas in the Northeast, cities in North and Central Thailand, as well as islands. The field trips to Poland were conducted in the Southern and Southwest part of the country. ${ }^{3}$ The study uses an ethnographic approach and includes participatory observation of everyday life in the facilities; qualitative guided interviews with operators, managers, staff, relatives and residents; and the analysis of the facilities' websites.

Data collection was conducted in seven facilities in Thailand. The selection of these facilities was first based on an Internet search in which we found 19 facilities. After exploring the websites to gain an initial

${ }^{3}$ Concrete locations are not mentioned, for reasons of anonymity. 
insight into the character of these facilities, we chose 11 to contact them. We selected them on the basis of differences in costs, size, location (ruralurban), resident composition and degrees of care required by their residents. One of these facilities declined its consent to our research, one was no longer operational and from one we did not get a response despite various attempts. The remaining facilities we visited on site. During our fieldwork we discarded another facility due to its recent opening and lack of residents. In Poland we included four facilities in the sample. The sampling strategy was also first based on an Internet search in which we found 32 facilities that offered their service (also) to people from Germany. In contrast to Thailand we contacted all of these facilities because it was unclear from their websites to what extent they actually managed to attract people from Germany. Ten facilities were unreachable despite repeated attempts by e-mail and phone. Thirteen facilities were excluded from the sample because six facilities were not operational, four had not (yet) attracted people from Germany and three because of Polish-German/English language barriers. The remaining nine facilities we visited on site. However, we found out that only four of them actually had German residents. The other five facilities had not been able to recruit residents from Germany (Großmann \& Schweppe 2018).

The results we present in this article are informed by the analysis of all of the empirical material collected. However, we especially rely on the data from two facilities (i.e. one in Thailand and one in Poland). Of particular relevance are the analyses of the facilities websites and the qualitative guided interviews we conducted with key actors involved in the running of these facilities, particularly the facility operator in the Thai facility and the care manager of the facility in Poland. Both actors were interviewed twice. To conduct the interviews, we started with a narration-generating stimulus stating our interests in care facilities targeted at people from Germany. We explained that we would like to learn about the development of the respective facility, everyday life and care delivery. Depending on the respective information given, we added questions about the problems and challenges they encountered, as well as about the qualification and number of staff, and the residents' biographical backgrounds. We also asked about their experiences with regard to the decision-making process of recruiting a person from Germany in the respective facility, 
International Journal of Ageing and Later Life

and the way they countered possible objections. Data analysis followed an inductive exploratory approach which was guided by grounded theory methodology (Strauss \& Corbin 1996). We began with the analysis of the interviews. They were coded and analysed line by line to identify potential key themes. Following the constant comparative method (Strauss \& Corbin 1996), we continuously compared the emerging themes with one other and explored theoretical ideas and concepts. This way ideas and concepts were refined, while new ones were also generated. We then analysed the websites, following the same analytical procedure as for the interviews. The findings from the websites and the interview analysis were then related to each other to further deepen our analysis and to specify the emerging arguments in their self-presentation and the theoretical categories (Corbin \& Strauss 2008).

The facilities chosen to illustrate our results were selected because both had achieved sustained take-up by German-speaking people over a longer period of time and were either expanding or had deliberately decided against expansion for reasons related to the facility concept (more on this is given below). Specifically, the facility in Poland was chosen because it was the only one that had successfully managed to establish itself for people from Germany in Poland during the study period (Großmann \& Schweppe 2018). It opened with 40 places and thereafter expanded to a capacity of 74 places due to high demand. The facility in Thailand is one of the first facilities there for German-speaking people. Since opening, it has attracted notably high demand, and generally fills any vacant places quickly. In one additional respect it is especially significant: our study reveals that the strategies it has developed to create acceptance in the German market are being adopted by other facilities in Thailand. Even if the organisational models vary in other facilities, we found that their arguments to gain acceptance by people from Germany were adopted to a large extent from this facility (Bender 2015).

\section{Criticism of Old Age Homes in Germany}

An important background to the emergence of old age care facilities abroad, as well as their positioning as a favourable care option for people from Germany, consists in criticism of residential old age care in Germany. 
A central problem is its high cost. The considerable cost burden is reflected in high co-payments which amounted to an average of 1.831 Euro monthly in 2018 (PKV 2018). It is also reflected in the large number of people who are unable to cover the costs of old age care facilities and require supplemental financial support from the state. In 2015, out of 450,674 recipients who received "Hilfe zur Pflege" [supplemental public care assistance] approximately $72 \%$ lived in old age care facilities (Statistisches Bundesamt 2015). Therefore, it is not surprising that almost $60 \%$ of the German population considers that residential old age care is barely affordable or not affordable at all (Eurobarometer 2007).

Severe criticism also points at the quality of care provided. A key focus of this criticism is the orientation of care to organisational rationalities at the expense of an orientation to the individuality of people needing care and their specific lifeworlds. This often goes along with the lack of their participation in the decision-making processes of how they wish to be cared for. Only rarely can they decide on their own daily routine and activities (Schneekloth \& Wahl 2009).

The dominance of the medical paradigm in old age residential care is another focus of criticism. When the long-term care insurance was introduced in Germany in 1995, the medical paradigm became firmly anchored in billable care (Jansen \& Klie 1999; Schweppe 2005, 2012). Due to the legal regulations, costs of services can normally only be billed if they relate to bodily or hygienic aspects. This often ignores, or is at the expense of, the social and emotional aspects in care. In addition, strict stipulations for the services that can be billed, according to which activities such as feeding or bathing are calculated on a per-minute basis, add weight to the critique of an increasingly visible standardisation of care (Behr 2015).

Another key problem is the highly precarious personnel situation. This is characterised by a considerable shortage of care workers, which is projected at almost half a million by the year 2030 (Horn et al. 2016; Rothgang et al. 2012). The precarious personnel situation is also expressed in qualification deficits, high personnel fluctuation, high workload and high case numbers (Schneekloth \& Wahl 2009). Accordingly, the care work is fast paced, giving little latitude to engage with the old people's individual needs.

Furthermore, violence is one of the central shortcomings of residential old age care in Germany. This includes physical and mental abuse, 
International Journal of Ageing and Later Life

neglect and avoidable restrictions of freedom and autonomy of action and decision-making (Görgen 2017), for example, through the (medically unjustified) use of sedatives to immobilise residents labelled as "aggressive" or "difficult" (Grassberger \& Püschel 2013: 250).

\section{The Emergence of Old Age Care Facilities for People from Germany in Poland and Thailand}

Even though these shortcomings and criticism play an important role in the emergence of old age care facilities abroad for people from Germany (Horn et al. 2016), so far there are no systematic studies on why the facilities emerged especially in Thailand and Poland. The considerable lower wage and living costs in both countries certainly provide favourable conditions to develop lower cost care alternatives compared to the high costs in Germany, and thereby address one of the main challenges of residential care in Germany. Also, the long and multilayered relations between both countries and Germany can be considered as favourable conditions for their emergence.

In the case of Poland, historical developments and interdependencies since the Second World War, along with extensive migration processes of people from Poland to Germany, are especially relevant (Loew 2017).

In addition, people from Poland play a significant role in the abovementioned employment of migrant care workers in private households. Even though there are no exact numbers, people from Poland play a significant role in the transnational care market that has developed between Poland and Germany. The following quote from a German news portal illustrates this well: "If nobody knows anymore (how to care for their older family members, added by the authors), you're guaranteed to be told: 'Well, go and get yourself a Pole. The Poles are the most important care stopgap of the nation"' (Maybaum 2017, translated by the authors).

Besides these favourable conditions, it is not clear whether there are other concrete conditions leading to the establishment of the facilities in Poland. Overall, the high costs of old age residential care in Germany seem to be of high relevance for their emergence. The lower care costs in the facilities in Poland as compared to Germany play a significant role in 
our data as well as in the media, and are presented as a prominent reason for their attractiveness. ${ }^{4}$ This points out that the facilities in Poland were envisioned as a response to a demand by people from Germany, and target a potential market by addressing a sensitive old age care problem in Germany. In addition to the low wage and living costs, the possibility of transferring benefits from the German long-term care insurance to Poland plays a further role in reducing out-of-pocket costs compared to Germany. ${ }^{5}$

Some interviews with the facility managers in Poland also indicate that the high number of people from Poland in Germany played a role in the establishment of the facilities, as it was assumed that the facilities in Poland would also offer an attractive option for care in old age of this target group. However, our data show that the facilities do not attract this target group; so far, people from Poland who live in Germany hardly make use of them.

The relation between Germany and Thailand is also marked by diverse cultural, economic and political ties (Stoffers 2014) and by a steady tourism stream of Germans to Thailand. Furthermore, Thailand has become a prominent destination for retirement migration from Germany (Jaisuekun 2017; Jaisuekun \& Sunanta 2016; Jöstl \& Wieser 2011). In addition, our study indicates that the facility, which we present below and which was the first one established in Thailand, had a significant impact on the establishment of further facilities. Our data show that facilities created later adopt some of the arguments formulated originally by this facility for why care abroad and especially in Thailand presents a promising alternative to old age care in Germany (Bender 2015). In addition, the biographies of the founders of the facilities provided favourable conditions for the emergence of the facilities in Thailand. All founders are Swiss or German. Biographically, they were connected to Thailand for many years, for example, through work experiences in Thailand or marriage

\footnotetext{
${ }^{4}$ This raises a potential question for future research, namely, through which processes was the knowledge about the high residential care costs as a main care problem in Germany made available in Poland and whether the above-mentioned transnational care market between Germany and Poland contributed to it.

${ }^{5}$ Benefits from the German long-term care insurance can only be transferred within the European Union.
} 
International Journal of Ageing and Later Life

to a partner from Thailand. This biographical entanglement provided an important knowledge base and sometimes material resources, such as the inheritance of land in Thailand in the case of Thai-German couples to set up a facility in Thailand, which often corresponded to their wish to permanently relocate their place of living and work to Thailand. In Poland, we could not observe similar processes.

Even though one might expect that the widespread retirement migration from Germany to Thailand had an impact on the emergence of the facilities, our study shows that hardly any of the residents were already living in Thailand before moving into the facilities. For the large majority of the residents, the choice of the particular facility equates therefore to a decision to migrate to Thailand (Bender et al. 2018).

\section{Criticism in Germany of Old Age Care Facilities Abroad}

Although the old age care facilities abroad promote themselves as far better care options than those in Germany, while at the same time being far more reasonably priced, opinion polls reveal high levels of scepticism about or rejection of care abroad. A representative survey (Konpress and Emnid 2013) showed that $85 \%$ of Germans reject the option of placing a relative in need of care in an old age care facility abroad, compared to $23 \%$ of Germans who generally reject placing a relative in need of care in an old age care facility. Only for 3\% of Germans the option of old age care abroad is an unqualified option, compared with $17 \%$ of Germans with regard to a placement in an old age care facility in general. The main reasons for rejecting the option of an old age care facility abroad are geographical distance and the desire to keep their relatives geographically close $(89 \%$ of respondents), the anticipation of language barriers and problems in communicating $(72 \%)$, the anticipation of challenges in dealing with a different culture $(71 \%)$ and fears that medical standards are not as high as in Germany (56\%). The same scepticism is voiced in the German media. Resorting to care abroad is often described by terms like "deportation" (Weingärtner 2012), dumping, inhumanity or a "forced disposal of the elderly" (Prantl 2012; translation by the authors).

In accordance with this criticism, it can also be empirically observed that - contrary to the discourse about the mass displacement of old age care abroad, propagated with the media catchword of "Granny 
export" (Kresge 2013) - the take-up of such care is a rather small-scale phenomenon, especially in Poland (Großmann \& Schweppe 2018).

Care facilities abroad challenge the principle of "ageing in place," which counts as one of the pivotal orientations of old age care in Germany. In normative discussions about "good care" in Germany, remaining in familiar surroundings is considered an important aspect. The same applies to residential care: a residential placement should be close to where a person previously lived (Mischke et al. 2015). Thus, the principle of "ageing in place" locates "good care" for older people within the local and - in the broadest sense - national context. The significance of this principle is also reflected in the previously mentioned reasons for rejecting placement in a residential care facility abroad. The unease about care facilities abroad is therefore twofold: they decouple residential care from familiar surroundings and the national context, and they require old people to migrate abroad for the purpose of care.

Against this background, old age care facilities abroad are not directly compatible with the orientations that define "desirable care" in Germany. Therefore, the question emerges how some of them succeeded in establishing themselves nonetheless, and how do they maintain themselves over several years in the German market? To answer these questions, in the following we will present the two old age care facilities in Thailand and in Poland.

\section{The Facility in Thailand: A "Loving and Respectful" One-to- One 24-Hour Care Arrangement}

The facility in Thailand is located in a village in the immediate vicinity of a mid-sized city in Thailand. It has a Thai name. It provides a space for 13 persons. It is specifically targeted at people from German-speaking countries, who either have dementia or are in need of permanent care for other reasons. It was founded and is run by a Germanophone European. The caregiving staff are recruited from Thailand. Despite quite high demand, the facility does not envisage an expansion (more on this below).

One of the facility's central characteristics is its 24-hour care provision. This is organised by allocating three Thai caregivers to each of the persons in need of care. These three carers work 8-hour shifts in rotation and are only responsible for their allocated resident, so that a constant 
International Journal of Ageing and Later Life

one-to-one care is available. In allocating the carers, the facility manager pays attention to their suitability to the individual needs and competences of the given residents. Regarding the language skills of the residents, the facility manager says, for example:

We now have three residents, they suffer from dementia (.) All three of them (.) have travelled quite a bit (.) and can speak good English, even now, despite their dementia. So for them, it really makes sense to (.) have carers who can speak English too.

The high staff ratio is also emphasised as important for individual care as it would allow for the delivery of care according to each residents' wishes, needs and special characteristics, the individual structuring of the daily activities, and to ensure individual care also during the night. On the facility's website it is explained that during the night, one of the resident's three carers lies beside the resident's bed and therefore the carer could respond immediately if the resident wakes up and requires support. It is also argued on the website that this individual care arrangement would eliminate the need to use restrictive measures such as physical restraints, the use of bed rails or sedating medication, which are present in old age care facilities in Germany (Newerla 2012).

The size of the facility is also considered beneficial and substantive to providing every resident with individual attention. The facility manager considers the small size as a crucial pillar of the facility and its care concept:

That's why I'm not really in favour of those ideas, of bigger projects. Of course, I was confronted with this question early on. I had investors who wanted to scale things up right away. But then it's the same as in Europe - then you're no better off than in Europe.

In this care arrangement tailored to the individuality of each resident, the importance of the relationship between the carers and the residents is emphasised. As the facility manager explains, the development of a positive relationship between the carers and the residents is especially significant to attend to the residents' specific needs.

In this regard, the specific quality ascribed to the Thai staff is of special importance and is marked as a particular hallmark of the facility. In this regard, the facility draws upon a widespread narrative about old people 
in Thai society according to which people in old age are treated with high respect, love and affection (Leifeld 2002; Thiesen n.d.). This argument is continuously reiterated by the facility manager and prominently displayed on the facility's web page, indicating that this special treatment would also be reflected in the facility's care work. It is also pointed out that caring for older people is considered an especially meaningful and socially recognised task in Thailand, resulting in distinct motivations to care for them.

The warmth, tenderness and physical closeness in caregiving, highlighted by the facility as a special seal of its care quality, are presented as characteristics that particularly address the needs of people with dementia. The arguments developed by the facility in this regard are that, along with the decline of verbal communication as the disease progresses, people with dementia would increasingly look for bodily contact. Likewise, Thai people's attitude towards older people, which is characterised by "great respect and deference," is also presented as impacting positively on people with dementia as it would strengthen mutual trust and the self-esteem of people with dementia. It is thus emphasised that the traits ascribed to the Thai caregivers are almost perfectly matched to the condition of dementia. In this way, Thai people are constructed as especially qualified carers for people with dementia, and the facility residents as ideally cared for addressees of the facility (Bender 2015).

In contrast to the high significance attached to physically close interaction with the residents, the facility relativises the significance of verbal communication. This argumentation comes into play against the background that the Thai staff generally speak little or no German. Also for the relativisation of verbal communication, the disease of dementia becomes relevant. The decline in verbal communication abilities of people with dementia is pointed out, along with the need to seek other forms of communication which, it is claimed, often expose entirely new resources and potentials of the residents. In addition, the facility argues that the avoidance of verbal communication can also result in positive and less conflict-prone relationships between residents and carers. In this regard, the facility refers to not further specified experiences that when family members or other carers communicated with dementia patients in the same language, in the event that the old person was dissatisfied or distressed, 
International Journal of Ageing and Later Life

the carers often felt a need to justify themselves which then could lead to mutual blaming or accusations. Precisely this could be avoided through non-verbal or other forms of communication.

The geographical distance from the country of origin is also relativised against the background of dementia. The facility manager recounted various situations in which the facility's residents went out walking in the neighbourhood of the facility with their carers and "recognised" houses of their previous environment in Europe. Implicitly, these narrations relativise the importance of specific places for feelings of familiarity for people with dementia because they rediscover previously familiar realities in other locations. This can be interpreted as an attempt to address the above-mentioned scepticism towards old age care abroad due to the geographical distance from the place of origin and its associated fears of potential alienation. According to the experiences recounted by the facility manager, geographical distance with regard to feelings of familiarity is rather unproblematic for residents with dementia.

In addition, the facility points out on its website that Thailand's warmer climate is another advantage for the residents. It is argued that, due to the warmer climate, some of the medication is dispensable and the residents would suffer less from colds and influenza.

With regard to costs, the facility web page states that cost details cannot be given in advance as these are always calculated individually to tailor the care to the specific resident. However, the website claims that the costs are generally less than half the cost of similar care in Germany.

\section{The Facility in Poland: German Standards at Low Costs ${ }^{6}$}

The facility in Poland opened in 2013. It is located on the outskirts of a small city. The facility opened with a capacity for 40 residents and expanded to 74 places due to high demand. It is run by a general manager and a care manager, who both come from Germany. The general manager, a business consultant, lives in Germany and is the primary contact for persons who are considering the facility as a caregiving option. The care manager lives in Poland and is responsible for the daily running of the facility. The caregiving staff are recruited from Poland.

${ }^{6}$ This part of the paper is based on Großmann and Schweppe (2018). 
On the website, the facility presents itself as an offer that promises "high standards of care at an affordable price." The prices of the facility are far below of those in Germany. In 2013, the monthly average cost of a place in a residential old age care facility for persons with medium care needs amounted to $€ 2530$ in Germany (Böcker et al. 2017), while in the facility in Poland the cost was between $€ 1400$ per month for a single occupancy room and $€ 1300$ for a double room.

The facility has a German name, which matches with its many other references to Germany. As can be seen, these references run like a common thread throughout the facility's self-presentation. For instance, in the pricing details right on the very first page of its website, it is mentioned that the costs include access to German radio and television stations. In another example, the care manager explained to us that the facility is equipped with German tableware so that the residents can feel "at home."

Great value is also placed on the German language. In addition to the website presenting the facility as a "German-speaking old age home in Poland," the carers' good German language skills are repeatedly pointed out in the interview with the care manager as well as on the website. A German-language 24-hour crisis helpline and German church service are also noted.

Reference is made to Germany also with regard to care. Both in the interview and on the website, it is underlined that the care is comparable with "German standards." When the care manager was asked what she meant by German standards, she pointed out that the facility "really is run like in Germany." In this regard, care documentation is emphasised in the interview as well as on the website, and singled out as a special seal of the quality of care provided as it would ensure individual care provision and the continuity of care. In addition, the care manager explains why care documentation is of particular importance to the facility, when she says:

(S)hould a resident apply for a higher level of care benefits from the German old age care insurance provider, the corresponding German assessment organization (German Medical Service) would conduct an on-site health assessment of this resident, and the facility's care documentation plays a crucial role in the decision-making process.

The second "German standard" that the care manager points out relates to the concept of activating care. In old age care in Germany, this concept 
International Journal of Ageing and Later Life

is of high significance, and legally anchored (German Social Security Act XI, Section 11 Para. 1). According to the law, old age care facilities need to provide "humane and activating care with due regard for human dignity."

As a seal of care quality, the care manager also highlights the staff's good professional qualifications. She argues that their qualifications are as good as in Germany, and maybe even better. She bases her argument on the fact that the facility only hires staff with professional training, and for nurses the professional training in Poland exceeds the one in Germany with 2 years.

Although the facility repeatedly emphasises the alignment of its orientation to old age care with Germany, it also reassures that it does not reproduces the shortcomings of care in Germany. In this regard, the far better staffing level is considered of crucial importance. The care manager says:

In Germany the staff ratio is one to ten or one to 15. That's abysmal and off the charts. And here it is one to five or one to six. That's a big difference.

Care workers in Germany are permanently rushed, she says, and can barely provide appropriate and good quality care. In contrast, her facility can provide a staff ratio of one carer to five or six residents. This makes a considerable difference to the care that is provided by her facility compared to Germany. The "very good staff ratio" allows staff "just to have time." "Having time" is considered a particular seal of quality for this facility. The care manager explains that this allows the staff to offer individual attention to each resident and to treat them with "love" and "affection." As evidence of how significant this is, she mentions the improved health status of many of the facility's residents and the emergence of new energy for life. She also points to the reduction of sedatives, and argues that this is the result of the quality of care that her facility provides. She mentions the example of one resident who arrived in the facility from Germany, "stuffed with medications" and in a bed-ridden state. Thanks to the reduction of "tranquillisers" that the conditions in her facility made possible, the resident regained mobility and was able to use a wheeled walker. Her previously aggressive behaviour had also reduced markedly. 


\section{Comparison of the Facilities}

Despite the considerable differences between the facilities, a comparison brings to light notable commonalities. These are evident in the themes that are taken up, even though they are dealt with differently.

\section{Language Differences}

Both facilities pick up on language differences between Germany and Poland and Germany and Thailand, respectively. The care facility in Poland attaches importance to its care staff's knowledge of the German language and considers its German language skills as a particular hallmark of the quality of care it offers. The Polish language goes unmentioned. The facility in Thailand deals with the linguistic difference in another way. On the one hand, the ability of caregivers and residents to communicate verbally is considered significant, provided that the residents are still capable of it. However, the "mother tongue" is not necessarily deemed important to verbal communication; the residents and the carers may also fall back on a common foreign language (in this case, English). On the other hand, the significance of verbal communication is relativised. Based on the assumption that the avoidance of verbal communication may result in positive and less conflict-prone relationships between residents and carers, non-verbal guidance of residents with dementia through difficult situations is said to work better. The personnel's lack of German language skills is turned into a resource (Bender 2015). As different as the strategies of the two facilities are, both are aimed at relativising the significance of language differences between the care staff and the residents.

\section{Geographical Distances}

Both facilities pick up on and deal with fears relating to geographical distances or alienation by cultural differences, which in Germany are associated with the use of care facilities abroad. Similar to the language differences, arguments are developed in both facilities to counteract these fears. The facility in Poland follows its strategy of dealing with differences by alignment with Germany. Specific objects or materialities like 
International Journal of Ageing and Later Life

German tableware and the German language are used to convey a sense of familiarity, home, continuity and habitude to the residents. The Thai facility, on the contrary, uses the disease of dementia to point out that familiarity can be identified by the residents in the surroundings of the Thai facility. By implication, the sense of familiarity as it is often understood in association with specific places, spaces, and familiar materialities ceases to exist because of the disease. Rather, it can be rediscovered in the reality of Thailand, without Thailand as such taking on any particular significance.

\section{The Quality of the Personnel}

The qualifications of the care staff are also an aspect taken up by both facilities. Staff qualifications are implicitly or explicitly conceptualised as better, or at least equivalent when compared to Germany. In the Thai facility, the resources of Thai culture - which are naturalistically ascribed to every Thai (and hence every Thai caregiver) - are emphasised and interpreted positively. The Thai culture is interpreted as valuable, and as a significant resource for the care arrangement within the care facility in Thailand. In relation to its offer, the Thai facility constructs this resource as more suited to the needs of people with dementia than could be managed in the German-speaking context. The care in the facility in Thailand, according to its underlying but not explicit argumentation, is better than in Germany for cultural reasons. In this respect, it also positions itself in relation to medically oriented care. It is not medicine that is called for but emotionality, physical closeness, and dignity.

The facility in Poland, in contrast, relies on professionalisation, as in Germany, and argues that the professional qualifications of its staff are at least comparable if not superior with those in Germany. This way, feared quality differences due to a lower level of training may be counteracted.

\section{The Quantity of Personnel}

In both facilities, the (very) much better staff ratio in comparison to Germany is held up as a special seal of quality. Due to the better staff ratio, in both cases the care arrangement is presented as qualitatively superior than in Germany. They can offer care arrangements which exceed the 
standards of residential old age care in Germany and address its criticism of scarce time and personnel resources - and, beyond that, at far lower prices than in Germany. The decisive reason why both facilities can dispose of such organisational realities at affordable prices is grounded in the very sizeable cost-of-living and wage-cost disparities that exist between Germany and Thailand and/or Poland.

Closely linked to the higher staff ratio is the use of medications. Both facilities point out that their higher staff ratio and the ensuing higher time resources allow them to dispense with unnecessary sedatives and instead to respond to individual needs such as an urge for physical activity. Hereby, they implicitly take up and respond to the widespread and criticised practice in Germany of "immobilization" by medication (Pflege-Report 2017).

\section{Making Old Age Care Abroad Legitimate}

Looking at the arguments used by the facilities to position themselves and the care concepts the facilities project, what is their significance for take-up of their provision by people from Germany?

To explore their significance, neo-institutional organisation theories prove to be insightful. These theories are based on an understanding that organisations cannot be described as self-contained structures independent of social influences. Instead, the social environment is conceptualised "as a crucial influencing factor which penetrates the boundaries of the organization, establishes itself within it, and even exerts a formative influence on its shape and its operative scope" (Koch \& Schemmann 2009: 22, quoted in Krawietz 2010: 252, translation by the authors). Accordingly, these theories argue that organisations need more than just material resources and task-related information to survive and point out the significance of establishing an accordance with socially shared values, normative expectations, and hence general rules and laws, to acquire legitimacy (Walgenbach \& Meyer 2008). Legitimacy is viewed as the decisive criterion for the survival of organisations (Walgenbach \& Meyer 2008). It is defined by Suchman (1995) as follows: "Legitimacy is a generalized perception or assumption that the actions of an entity are desirable, proper, or appropriate within some socially constructed system of norms, values, beliefs, and definitions" (574). Once an organisation has legitimacy, it can 
International Journal of Ageing and Later Life

build on the support of other important actors. This support is crucial to the organisation's survival. Legitimacy is always linked to a certain social field and/or a particular reference group. This reference group is the "legitimatory resonance space of institutions" (Rehberg 1995, cited from Walgenbach \& Meyer 2008: 65; translation by the authors) and the social instance of control which confers legitimacy on the organisation. An organisation is deemed to be legitimate when it fulfils this group's expectations (Walgenbach \& Meyer 2008).

The substantial criticism and scepticism in Germany towards old age care abroad, and particularly the fact that the facilities do not directly align with the socially shared values and normative expectations inherent in the prominent guiding principle of ageing in place, indicate that opting for an old age care facility abroad does not immediately appear as something that "is the right thing to do" (Suchman 1995: 579) for potential users in Germany. If the facilities want to secure their existence on the basis of take up by people from Germany, they face the challenge of presenting old age care abroad as a legitimate option for them by establishing compatibility with socially shared values and normative expectations.

How this is done is evidenced in the analysis of the two facilities. A central element for both facilities is constituted by their explicit or implicit references to the structures, practices and public discourses of residential old age care in Germany. This encompasses both the criticism of old age residential care in Germany and criticisms of care facilities for Germans abroad. It is precisely in terms of the themes mentioned above - language differences, geographical distances, as well as the quality and quantity of care personnel - that these criticisms are taken up.

The two facilities tackle these themes in different ways. The facility in Poland projects itself as a facility which, although located in Poland, is not to be understood as a "Polish" facility for people from Germany, but rather as a "German" facility in Poland (Großmann \& Schweppe 2018). It follows a concept that not only aims to align with "German culture" as much as possible, but it orientates its care concept to Germany, too. According to its arguments, the availability of more personnel makes it possible to offer an old age care facility where the German care concepts, which in principle are considered to be good, can actually be realised in their entirety. Ultimately, its motto is "Just like in Germany - only better" 
(Großmann \& Schweppe 2018); it thus positions itself as a qualitatively superior old age care facility in comparison to Germany.

In contrast, the facility in Thailand projects itself as a highly staff-intensive, individualised old age care facility, and by ascribing Thailand's specific cultural resources with regard to older people and old age care, it is presented as a facility in which the residents are treated with dignity, emotionality and physical closeness, which particularly fits the specific needs of people with dementia. In this case, very little of the reality of old age care in Germany is transferred to the facility. At the same time, all of the significant points referencing the criticisms of residential care in Germany are discursively integrated and addressed to justify and transform the care reality into a different and better version of care - without ever letting this comparison become explicit.

As much as the self-presentations of the facilities differ, their common strategy is to project themselves as a better care option in comparison to residential care in Germany. In doing so, they draw on ideas of "good care" within Germany, which are the basis for the criticisms of residential care pointed out before. Simultaneously, the facilities attempt to minimise the scepticism about or the rejection of care facilities abroad which is mainly caused by the irritation of the principle of ageing in place as a main principle of old age care in Germany. In the case of the facility in Thailand, this is done by challenging the underlying assumption of this principle. In this regard, the significance of specific places for feelings of familiarity and the significance of verbal communication or communication in the mother tongue in the context of dementia are relativised. In the case of the facility in Poland, differences and feared experiences of alienation due to the different national context are countered by equipping the facility with materialities from Germany and by highlighting the staff's German language skills.

Seen in this way, the self-presentations can be understood as legitimation strategies aimed at establishing an "accordance with socially constructed systems of norms, values, beliefs or definitions" (Suchman 1995: 574) with regard to conception of "good care" in old age in Germany. In these legitimation strategies, (discursive) knowledge about the respective national contexts with regard to old age care, as well as the concrete availability of resources in the respective countries, becomes so interlinked that the space in which the facility is located and the resonance space in 
International Journal of Ageing and Later Life

Germany addressed by the facilities merge with one another. The facilities' legitimation strategies can be called transnational in both cases, in that they deliberately interlink resources from the different countries involved, both on the discursive knowledge level and on the level of concrete materialities, thereby bringing into being something new: legitimate care facilities for people from Germany abroad, within which (borrowing the words of Hoch \& Schemmann) border-crossing interlinkages establish themselves and exert a formative influence on their shape and their operative scope (Koch \& Schemmann 2009, quoted in Krawietz 2010: 252). In this regard, our study adds a new facet to the conceptualisation of old age care facilities for Germans abroad as transnational organisations (Bender et al. 2017, 2018).

The strategies for establishing this legitimacy and its connectivity to the German market differ, and must differ, because each country has different resources that can be utilised to fruitful effect for the German-speaking resonance space. For example, the 1:1 care arrangement in Thailand can only be offered because of the considerable wage and cost-of-living disparities with Germany. This disparity is much smaller in Poland, where a 1:1 care arrangement would entail costs that would hardly be a viable option for people from Germany. By the same token, a "German-speaking" facility would hardly be feasible in Thailand due to the lack of German-speaking personnel.

\section{Conclusion}

Our results show that both facilities legitimise themselves particularly by emphasising the special care they offer and its quality. In the process, both of them reveal Germany and the discourses circulating in Germany to be the resonance space for the evaluation of care arrangements. They position themselves as qualitatively superior in relation to current residential old age care realities in Germany, while at the same time countering possible fears of potential difficulties linked to moving care abroad. Our study of the facilities in Poland particularly, the majority of which stresses their lower prices and position themselves as "low cost facilities for people from Germany," shows that they barely manage to attract an appreciable number of people from Germany, if any at all (Großmann \& Schweppe 
2018). Low costs alone do not pave the way into the facilities abroad. As Großmann and Schweppe state (2018: 17):

By offering lower costs they do address a severe problem of old age care facilities in Germany but (...) they do not take up or refute the arguments that reject the use of a care facility abroad due to linguistic or cultural differences, fears of alienation or which associate poor quality with care abroad. Compared to the argumentation of the facility projecting itself by 'Just like in Germany, only better', these facilities rather position themselves as 'low cost facilities for people from Germany'.

Suchman (1995) argues that to positively answer the question 'is it the right thing to do', which he considers as an important element to accord legitimacy "reflects a positive normative evaluation of the organisation and its activities" and depends on "whether the activity effectively promotes societal welfare, as defined by the audience's socially construed value system" (579). The relatively high take-up of the facility presented here by people from Germany, with the relatives often taking an important part in the decision-making process, points to the significance people attach to quality old age care and to knowing that their family members with long-term care needs will be well looked after.

From this perspective, our results also show that care abroad is not - as sometimes propagated in the media - about "deporting" and "dumping" older people with care needs, but it is more about concern and the search for better care options.

Our results show some similarities with studies examining the placement agencies for migrant care workers for private households and their establishment old age care market. A decisive element in their case, too, is the construction of a care option as being qualitatively superior compared to the other alternatives available in Germany. These agencies position themselves as actors making "their commercial offer of care (...) explicitly as a more social and human alternative to the taylorized health care provided by the public sector" (Schwiter et al. 2014: 213; translation by the authors; also Krawietz 2014). Seen in this light, the establishment of new actors in the old age care market is a lucrative business, which is grounded in the concerns about, and the search for, more humanly and dignified old care options as a consequence of the public care system's shortcomings in Germany. Our research shows, however, that 
International Journal of Ageing and Later Life

some facilities hold up to their promises better than others. In fact, due to the diversity of old age facilities in Thailand as well as in Poland, it is difficult to draw simple conclusions. Careful case-by-case analysis is required to scrutinise whether and how these facilities offer old age care options that go beyond the current shortcomings of old age care in Germany (Horn et al. 2016).

\section{Corresponding author}

Cornelia Schweppe, Institute of Education, Johannes Gutenberg University, Georg-Forster-Gebäude, Jakob Welder Weg 12, DE-55099 Mainz, Germany. Email: schweppc@uni-mainz.de

\section{References}

Arend, S. (2017). Sorge(n)volle Zustände. In S. Arend \& T. Klie (eds.), Wer pflegt Deutschland. Transnationale Pflegekräfte - Analysen, Erfahrungen, Konzept [Who Cares in Germany. Transnatinal Care Workers - Analysis, Experiences, Conzept] (pp. 11-30). Hannover: Vincentz Network.

Behr, T. (ed.). (2015). Aufbruch Pflege. Hintergründe - Analysen Entwicklungsperspektiven [Changing Old Age Care. Backgrounds, Analysis, Development Perspectives]. Wiesbaden: Springer.

Bender, D. (2015). 'Doing discourse for moving care recipients'. Pflegeheime für deutschsprachige demenzkranke Menschen in Thailand 'salonfähig' machen [To make old age care homes for German-speaking people with Dementia in Thailand respectable]. Zeitschrift für Qualitative Forschung 16(1): 73-98.

Bender, D., Hollstein, T. \& Schweppe, C. (2017). The emergence of care facilities in Thailand for older German-speaking people: Structural backgrounds and facility operators as transnational actors. European Journal of Ageing 14(4): 365-374.

Bender, D., Hollstein, T. \& Schweppe, C. (2018). Old age facilities for German-speaking people in Thailand - A new facet of international migration in old age. Journal of Ethnic and Migration Studies. Published online: 12 Sep 2018. doi: 10.1080/1369183X.2018.1521266.

Böcker, A., Horn, V. \& Schweppe, C. (2017). Old age care regimes and the emergence of transnational long-term care arrangements for the 
elderly. In L. Good Gingrich \& S. Köngeter (eds.), Transnational Social Policy, Social Welfare in a World on the Move (pp. 222-242). New York: Routledge.

Corbin, J. \& Strauss, A. (2008). Basics of Qualitative Research. Techniques and Procedures for Developing Grounded Theory (3rd ed.). Los Angeles, CA: Sage.

Engelmann, D., Gohde, J., Künzel, G. \& Schmidt, S. (2013). Gute Pflege vor Ort. Das Recht auf eigenständiges Leben im Alter [Good Local Old Age Care. The Right to Live Indpendently in Old Age]. Bonn: Friedrich-Ebert-Stiftung.

Eurobarometer (2007). Health and long-term care in European Union. Special Eurobarmeter 283/Wave 67.3. Brussels: European Commission.

Görgen, T. (2017). Wissen über das Phänomen Gewalt in der Pflege [Knowledge about violence in old age care]. In Zentrum für Qualität in der Pflege (ed.), ZQP Report. Gewaltprävention in der Pflege [ZQP Report. Preventing Violence in Old Age Care] (pp. 8-12). Berlin. Available on https://www.zqp.de/wp-content/uploads/Report_Gewalt_Praevention_Pflege_Alte_Menschen.pdf (Accessed: April 23, 2018).

Grassberger, M. \& Püschel, K. (eds.). (2013). Forensische Gerontologie. Gewalt gegen alte Menschen [Forensic Gerontology. Violence against Old People]. Springer: Wiesbaden.

Großmann, S. \& Schweppe, C. (2018). Just like in Germany, only better? Oldage care facilities in Poland for people from Germany and the question of legitimacy. Ageing \& Society 1-19. doi: 10.1017/S0144686X18001290.

Hahn, A. (2012). Jauch-Talk zur Altenpflege. Darf man Oma nach Thailand abschieben? [Jauch-Talk about Old Age Care. May One Deport Granma to Thailand?] Available on https://www.bild.de/politik/inland/guenther-jauch/ darf-man-oma-nach-thailand-abschieben-27038224.bild. html (Accessed: May 22, 2018).

Horn, V., Schweppe, C., Bender, D. \& Hollstein, T. (2016). “Moving (for) elder care abroad": The fragile promises of old age care facilities for elderly Germans in Thailand. In V. Horn \& C. Schweppe (eds.), Transnational Aging. Current Insights and Future Challenges (pp. 163-177). New York: Routledge.

Jaisuekun, J. (2017). A search for a better life. Economic motivation of the German relocation to Pattaya. Walailak Journal of Social Science 10(2): 41-80. 
International Journal of Ageing and Later Life

Jaisuekun, K. \& Sunanta, S. (2016). Lifestyle migration in Thailand. A case study of German migrants in Pattaya. Thammasat Review 19(2): 89-103.

Jansen, B. \& Klie, T. (1999). Häuslichkeit [Domesticity]. In B. Jansen, F. Karl, H. Radebold \& R. Schmitz-Scherzer (eds.), Soziale Gerontologie [Social Gerontology] (pp. 521-539). Weinheim: Beltz.

Jöstl, J. \& Wieser, B. (2011). Auf der Suche nach dem Paradies? Einblicke in eine Studie zu "Amenity Migration" in Cha-am und Hua-Hin, Thailand [Sercing for paradies. Insights into a study on "amenity migration" in Cha-am Hua-Hin, Thailand]. ASEAS Austrian Journal of South-East Asian Studies 4(1): 166-172.

Konpress and Emnid. (2013). Pflege im Ausland - im Alter ins Exil? [Old Age Care Abroad - Aging in Exil?]. Available on http://konpress. de/wp-content/uploads/Emnid-Repr\%C3\% A4sentativbefragung-Pflege-im-Ausland-final.pdf (Accessed: June 13, 2018).

Krawietz, J. (2010). Pflegearbeit unter Legitimierungsdruck - Vermittlunggsagenturen im transnationalen Organisationsfeld [Old age care work under pressure of legitimation. recruitment agencies in a transnational organizational field]. In K. Scheiwe \& J. Krawietz (eds.), Transnationale Sorgearbeit. Rechtliche Rahmenbedingungen und gesellschaftliche Praxis [Transnational Care Work. Legal Frameworks and Social Practice] (pp. 249-276). Wiesbaden: Springer.

Krawietz, J. (2014). Pflege grenzüberschreitend organisieren. Eine Studie zur Vermittlung von Care-Arbeit [Organizing Care across Borders. A Study on Recruitung Care Work]. Frankfurt am Main: Mabuse.

Kresge, N. (2013). 'Grandma export' exposes Germany's struggle with care. The Japan Times. Available on: https://www.japantimes.co.jp/ news / 2013/09/24/world/ social-issues-world/grandma-exportexposes-germanys-struggle-with-care/\#.WwPsvkxuLNM (Accessed: May 22, 2018).

Leifeld, U. (2002). "But They Don't Know My View." Interkulturelle Kommunikationskonflikte thailändischer und deutscher Flugbegleiter am Arbeitsplatz [Intercultural Communication Conflicts between Thai and German Flight Attendants at Work]. Münster: LIT.

Loew, P. (2017). Unsichtbar? Polinnen und Polen in Deutschland - die zweitgrößte Zuwanderergruppe [Invisible? Poles in Germany - The second largest immigration group]. Available on: http://www.bpb. 
de/gesellschaft/migration/kurzdossiers/256398/polnische-diaspora (Accessed: January 20, 2019).

Maybaum, M. (2017). Hilfebeider Pflege daheim: "Dannholt Euch doch'ne Polin." [Help for Old Age Care at Home: "Just Get a Pole"]. Available on https:/ / www.nrz.de/region/dann-holt-euch-doch-ne-polin-id210073997.html (Accessed: February 22, 2018).

Mischke, C., Koppitz, A. L., Dreizler, J. \& Händler-Schuster, D. (2015). Eintritt ins Pflegeheim: Das Erleben der Entscheidung aus der Perspektive der Pflegeheimbewohnerinnen und Pflegeheimbewohner [Entering a nursing home: Experiencing the decision from the perspective of nursing home residents]. Journal für Qualitative Forschung in Pflege- und Gesundheitswissenschaft 2(1): 72-81.

Newerla, A. (2012). Verwirrte pflegen, verwirrte Pflege? Handlungsprobleme und Handlungsstrategien in der stationären Pflege von Menschen mit Demenz - eine ethnographische Studie [To Care for the Confused, Confused Care? Problems and Strategies in Residential Care of People with Dementia. An Ethnographic Study]. Berlin: LIT Verlag.

Pflege-Report. (2017). Pflegeheimbewohner erhalten zu viele Psychopharmaka [Residents of old age care homes receive too many psychotropic drugs]. Available on http://aok-bv.de/presse/pressemitteilungen/2017/index_18363.html (Accessed: August 30, 2018).

PKV (Verband der privaten Krankenkassen). (2018). Die Finanzierungslücke der Pflegeversicherung ist erneut gewachsen [The Funding Gap of the LongTerm Care Insurance has Grown Again]. Available on https://www. pkv.de/presse/meldungen/finanzierungsluecke-der-pflegeversicherung-ist-erneut-gewachsen (Accessed: September 22, 2018).

Posener, A. (2014). Deutschland wird Weltmeister im Oma-Export [Germany will be the Champion of Exporting Granma]. Available on https://www. welt.de/kultur/article133590183/Deutschland-wird-Weltmeister-imOma-Export.html (Accessed: June 28, 2018).

Prantl, H. (2012). Die verrückte Idee vom Greisen-Export. Pflegeheime im Ausland [The Crazy Idea of Exporting Old People. Old Age Care Facilities Abroad]. Available on http://www.sueddeutsche.de/politik/pflegeheime-im-ausland-die-verrueckte-idee-vom-greisen-export-1.1512615 (Accessed: May 08, 2018).

Rothgang, H., Müller, R. \& Unger, R. (2012). Themenreport "Pflege 2030." Was ist zu erwarten - was ist zu tun? [Themantic report "old age care 
International Journal of Ageing and Later Life

2030." What to expect - What should be done?]. Available on https:/ / www.bertelsmann-stiftung.de/fileadmin/files/BSt/Publikationen/ GrauePublikationen/GP_Themenreport_Pflege_2030.pdf (Accessed: July 04, 2018).

Schneekloth, U. \& Wahl, H.-W. (2009). Pflegebedarf und Versorgungssituation bei älteren Menschen in Heimen. Demenz, Angehörige und Freiwillige, Beispiele für "Good Practice" [Care Needs and the Care Situation of Older People in Residential Care. Dementia, Family Member and Volunteer, "Good Practive" Example]. Stuttgart: Kohlhammer.

Schweppe, C. (2005). Soziale Altenarbeit [Social work with elder people]. In W. Thole (ed.), Grundriss Soziale Arbeit. Ein einführendes Handbuch [Social Work. An Introductory Handbook] (pp. 331-348). Opladen: VS.

Schweppe, C. (2012). Altenarbeit: Altenhilfe, Altenpflege, Altenbildung [Old age care, old age education]. In: H.-H. Krüger \& T. Rauschenbach (eds.), Einführung in die Arbeitsfelder des Bildungs- und Sozialwesens [Introduction to Fields of Social Work and Education] (5th ed., thoroughly revised and expanded revision, pp. 187-208). Opladen: Barbara Budrich.

Schwiter, K., Berndt, C. \& Schilling, L. (2014). Ein sorgender Markt: Wie transnationale Vermittlungsagenturen für Seniorenbetreuung Im/ mobilität, Ethnizität und Geschlecht in Wert setzen. The Caring Market. How Transnational Recruitment Agencies Make Use of Im/mobility, Ethnicity and Gender). Geographische Zeitschrift 102(4): 212-231.

Schwiter, K., Berndt, C. \& Truong, J. (2018). Neoliberal austerity and the marketization of elderly care. Social and Cultural Geography 19(3): 379-399.

Statistisches Bundesamt. (2015). 20 Jahre Pflegeversicherung: Immer mehr auf Hilfe zur Pflege angewiesen [20 Years of Long-Term Care Insurance: More and More People Depent on Care Support]. Available on https://www. destatis.de/DE/ZahlenFakten/ImFokus/Soziales/PflegebeduerftigeSozialhilfe.html (Accessed: May 20, 2018).

Stiftung Warentest. (2017). Helferinnen aus dem Osten [Helpers from the East]. test.de: 88-94.

Stoffers, A. (2014). Thailand und Deutschland. Wirtschaft, Politik, Kultur [Thailand and Germany. Economy, Politics, Culture]. Berlin: Springer Verlag. 
Strauss, A. \& Corbin, J. (1996). Grounded Theory. Grundlagen qualitativer Sozialforschung [Foundations of Qualitative Research]. Weinheim: Beltz \& Psychologie Verlags Union.

Suchman, M. C. (1995). Managing legitimacy: Strategic and institutional approaches. Academy of Management Journal 20(3): 571-610.

Thiesen, H. K. (n.d.). Altersruhesitz in Thailand [Retiring in Thailand]. Available on http://www.siam-info.de/auswandern/altersruhesitz.html (Accessed: January 21, 2019).

Toyota, M. \& Thang, L. L. (2017). Transnational retirement mobility as processes of identity negotiation: The case of Japanese in South-east Asia. Identities 24(5): 557-572.

Toyota, M. \& Xiang, B. (2012). The emerging transnational 'retirement industry' in Southeast Asia. The International Journal of Sociology and Social Policy 32(11/12): 708-719.

Walgenbach, P. \& Meyer, R. (2008). Neoinstitutionalistische Organisationstheorie [Neoinstitutional Organization Theory]. Stuttgart: Verlag W. Kohlhammer.

Weingärtner, C. (2012). Darum ist Pflege so teuer. Gewalt im Altenheim Angst vor Abschiebung ins Ausland [That Is Why Old Age Care Is So Expensive. Violence in Residential Old Age Care - The Fear of Being Deported Abroad]. Available on https://www.bild.de/ratgeber/2012/ pflegeversicherung/darum-ist-pflege-so-teuer-27216272.bild.html (Accessed: May 08, 2018). 
